\title{
A Chat with Deterrence Scholar Brian Forst: A Tribute to Hans Zeisel
}

\author{
Brian Forst ${ }^{1}$ Interviewed by Robert M. Worley ${ }^{2}$
}

\begin{abstract}
[Article copies available for a fee from The Transformative Studies Institute. E-mail address: journal@transformativestudies.org Website: http://www.transformativestudies.org (c2022 by The Transformative Studies Institute. All rights reserved.]
\end{abstract}

RW: Our interview for this edition of Theory in Action is with Brian Forst, Professor Emeritus of Justice, Law and Criminology at the American University's School of Public Affairs, in Washington, DC. Before his 25 years of teaching and research at AU, Brian was director of research at the Institute for Law and Social Research (1974-85) and the

\footnotetext{
${ }^{1}$ Brian Forst is Professor of Justice, Law and Criminology at the American University School of Public Affairs. He joined the AU faculty in 1992, following three years on the George Washington University faculty. Before that, he was director of research at the Institute for Law and Social Research (1977-85) and the Police Foundation (1985-89). He was Visiting Professor in Residence at the University of California, Irvine, for the fall 2017 term. His research on errors of justice, prosecution, policing, terrorism, and the deterrent effect of the death penalty is cited extensively. He has published nine books and over 100 refereed articles, book chapters, encyclopedia entries, and monographs. His book, Errors of Justice: Nature, Sources and Remedies (Cambridge University Press), was named Book of the Year for 2006 by the Academy of Criminal Justice Sciences. The Cambridge University Press released his book, Terrorism, Crime, and Public Policy, in the fall of 2008. Professor Forst chaired the Justice, Law \& Criminology Department's doctoral program from 2000 to 2010 and supervised eleven doctoral dissertations from 2000 to 2016. He was awarded the School of Public Affairs Bernard H. Ross Teaching Excellence Award in 2002 and the School's Outstanding Scholarship Award in 2008 and 2011. He was a voting member of the D.C. Sentencing Commission from 2004 through 2010. He played cello with the AU Orchestra in 1998.
}

${ }^{2}$ Robert M. Worley, Ph.D., is Associate Professor and Director of the Criminal Justice Program at Lamar University. Robert has published extensively on "inappropriate relationships" that occur between inmates and correctional officers. He has been interviewed by Reuters, the New York Times, the Houston Chronicle, the Dallas Morning News, and the Marshall Project, as well as other media outlets. Robert is Coeditor (w/ Vidisha B. Worley) of the Encyclopedia of American Prisons and Jails (ABCClio). His work has appeared in journals such as Deviant Behavior, Criminal Law Bulletin, American Journal of Criminal Justice, Security Journal, and Criminal Justice Review, among others. Robert is currently an Associate Editor of Deviant Behavior and the Book Review Editor of Theory in Action. 